DOI: $10.14451 / 2.161 .21$

\title{
ЭВОЛЮЦИЯ ИНСТИТУТА ДИСЦИПЛИНАРНОЙ ОТВЕТСТВЕННОСТИ СУДЕЙ В РОССИИ
}

\author{
(c) 2021 Финогентова Ольга Евгеньевна \\ доктор юридических наук, профессор кафедры теории и истории государства и права \\ Балтийский федеральный университет им. И. Канта, Россия, Калининград \\ E-mail: finogentovaoe@mail.ru
}

(c) 2021 Понимаш Алексей Алексеевич

магистр 3 курса Юридического института

Балтийский федеральный университет им. И. Канта, Россия, Калининград

E-mail: ponimash2013@yandex.ru

В данной статье авторами проводится анализ и дается оценка существующим на настоящий момент в современной российской юридической науке концепциям периодизации развития и становления института ответственности судей. Устанавливается значение института дисциплинарной ответственности судей для развития современной отечественной правовой системы. Устанавливаются особенности правового статуса судей в Российской Федерации.

Ключевые слова: периодизация, дисциплинарная ответственность судей, судебная власть, прекращение полномочий судьи, независимость судей, юридическая ответственность.

Создание независимой и эффективной, отвечающей требованиям времени судебной власти является одним из основополагающих требований в демократическом правовом государстве. Статьей 120 Конституции Российской Федерации [8] закреплен принцип независимости судей, статьей 121 - принцип их несменяемости, а также возможность прекращения полномочий судей только в порядке, закрепленном федеральным законодательством.

С 1992 года был принят ряд нормативных актов $[13,14,9]$, а также был внесен ряд изменений в законодательные нормы [10,11,12], которые регулировали институт дисциплинарной ответственности судей. Причем мнение законодателя колебалось от полного отказа от института дисциплинарной ответственности, до его возвращения и создания механизма привлечения судей к дисциплинарной ответственности. Этот вопрос и в настоящий момент продолжает оставаться крайне актуальным. Статистические данные указывают на то, что данный механизм достаточно активно применяется. Так, в период с 2014 года по 2019 год более 1,6 тыс. российских судей были привлечены к дисциплинарной ответственности: 34\% из них получили замечания, 54\% вынесено предупреждение. Прекращены полномочия 125 судей, что составляет 12\% [3]. Таким образом, границы неприкосновенности и ответственности судей в их профессиональной деятельности требуют тщательного изучения и оценки.

Проблема дисциплинарной ответственности судей напрямую связана с правовым статусом судьи. С одной стороны судья должен действовать самостоятельно и независимо, так как это гарантировано Конституцией Российской Федерации. С другой стороны, судья осуществляет свою деятельность в рамках определенной иерархической структуры и судейской корпорации, должен выполнять четко закрепленные в законодательстве требования к порядку осуществления правосудия, нарушение которых влечет за собой для судьи наступление юридической ответственности.

Принцип независимости судей заложен в ст. 120 Конституции и детализирован рядом федеральных и федеральных конституционных законов Российской Федерации. Однако независимость судьи не безгранична, и ее обратной стороной является ответственность - за принятые решения и за свои действия. Именно поэтому И. С. Кузнецова считает, что ответственность судей возможна лишь за пределами его неприкосновенности.

Институт дисциплинарной ответственности судей - это не новшество для отечественной системы права, он имеет давние корни и на протяжении исторического пути развития претерпевал множество изменений. Выделяют- 
ся несколько этапов развития этого института в России, но среди авторов исследовавших эту проблему нет единства мнений.

Д.В.Володина рассматривает историю становления и развития института ответственности судей как совокупность восьми этапов [4, с. 11-12]. Первые три этапа охватывают период от конца XIV века до судебной реформы 1864 года. Для этого периода характерно развитие законодательства о судьях, в том числе о запретах в их деятельности и соответствующих санкциях. В частности, для российского законодательства о судьях в период Российской империи, предполагалось наличие личной, дисциплинарной, гражданской и уголовной ответственности судей за причинение вреда при отправлении правосудия. Четвертый этап длится до 1917 года и характеризуется детальной регламентацией правовых основ ответственности судей. Пятый и шестой этапы - это советский период от 1917 года по 1992 год, для которого характерно следующее противоречие: с одной стороны, формально принцип дисциплинарной ответственности судей не был нормативно закреплен, с другой стороны, отдельные положения дисциплинарной ответственности существовали в нормах об уголовной и процессуальной ответственности. Седьмой и восьмой этапы охватывают современную историю развития института дисциплинарной ответственности судей с 1992 года по настоящее время: она характеризуется нестабильностью подхода законодателя, который то ликвидировал его, то возвращал. Тем не менее, в настоящий момент положения о дисциплинарной ответственности судей нормативно закреплены и имеют практику применения.

По мнению авторов, выделение такого количества этапов научно не обосновано, представленная автором периодизация не соответствует этапам развития государственно-правовых институтов России.

Интересным, но также на взгляд авторов не вполне совсем обоснованным видится подход М.Л. Позднякова, который выделяет следующие этапы развития изучаемого института:

1) дореволюционный этап - до 1917 года;

2) советский этап - 1917-1991 годы;

3) постсоветский (современный) этап после 1991 года [15, с. 7].

Данная периодизация, на взгляд авторов, так же не является достаточно обоснованной, поскольку не ясны критерии выделения этапов, и не понятно основание объединения в одном этапе всей Российской дореволюционной истории. По мнению Г.Е.Агеева и С.А.Бурцев институт дисциплинарной ответственности судей в России начинается в петровскую эпоху. В этот период, впервые в российской истории, вводится не только надзор за деятельностью судейского корпуса, но и создается система привлечения его сотрудников к ответственности за должностные нарушения [1, с. 97]. Далее авторы выделяют советский и постсоветский периоды. По нашему мнению, такая позиция не заслуживает поддержки, так как еще в Киевской Руси принимались документы, закрепляющие те или иные санкции за совершение судьей какого-то проступка. Новгородская судная грамота, вводила штраф в случае неявки судьи-докладчика в вышестоящий суд, волокиту, несвоевременное рассмотрение либо непринятие решения судьей по рассматриваемому спору [5, с. 7]. Далее Судебники 1497 года, 1550 года, Соборное уложение 1649 года содержали и другие нормы, которые можно отнести к нормам регулирования ответственности судьи, в том числе дисциплинарной.

По мнению В.К. Аулова, следует выделять четыре этапа, соответствующие срокам действия нормативных правовых актов и переломным моментам развития системы органов государственной власти [2, с. 8]. По его мнению, развитие института дисциплинарной ответственности судей в России начинается только с 1864 года года судебной реформы, затем автор выделяет в советском периоде два этапа, разделенные 1948 годом, когда Верховным Советом СССР было принято Положение о дисциплинарной ответственности судей. Четвертый этап - современный, начавшийся в 1992 году с принятием Закона Российской Федерации «О статусе судей в Российской Федерации».

По нашему мнению, наиболее научно обоснованными подходами к периодизации развития института дисциплинарной ответственности в России являются позиции авторов, выделяющих четыре этапа [6, с. 200].

Первый этап - с X века до 1864 года - характеризуется отсутствием четко закрепленных положений дисциплинарной ответственности судей, однако закреплением отдельных ее элементов в различных законах.

Второй этап - с 1864 года до 1917 года. По мнению П.А.Дунюшкина, именно 1864 год стал переломным моментом в истории судебного 
законодательства, так как в ходе судебной реформы был законодательно закреплен институт судейства вообще и правовые его основы в частности, в том числе положения о дисциплинарной ответственности судей.

Третий этап - с 1917 года и до 1991 года. В этот период отношение власти к институту дисциплинарной ответственности судей колеблется: от его ликвидации до восстановления, от самостоятельности судей до их подчинения партийному аппарату.

Четвертый этап с 1991 года по настоящее время. Этот этап связан с проведением судебной реформы, которая сформировала современные правовые реалии института дисциплинарной ответственности судей, опираясь на положительный опыт Российской истории.

В настоящее время процесс реформирования судебной системы продолжается, затрагивает это и вопрос дисциплинарной ответственности судей, что выражается, в основном, в порядке их привлечения к ответственности. В частности, в 2018 году Президентом В.В.Пу- тиным в Государственную Думу Федерального Собрания РФ был внесен проект федерального закона, предусматривающий применение новой меры дисциплинарной ответственности в виде понижения судьи в квалификационном классе за существенное нарушение положений Закона РФ «О статусе судей в Российской Федерации» и (или) Кодекса судейской этики в том случае, если судья ранее уже подвергался дисциплинарному взысканию. Федеральным законом от 29.07.2018 № 243-Ф3 [12] это изменение было принято, расширив тем самым перечень дисциплинарных взысканий по отношению к судьям.

И хотя, некоторые авторы считают, что: «современный период реформирования судебной системы характеризуется разбросанностью норм, определяющих порядок применения дисциплинарной ответственности к судьям» [6, с. 26]. Но, тем не менее, в настоящее время законодательством достаточно четко регламентируется вопрос дисциплинарной ответственности судей, при этом остаются проблемы как толкования данных норм, так и их применения.

\section{Библиографический список}

1. Агеева Г.Е. Дисциплинарная ответственность судей в общей системе юридической ответственности / Г. Е.Агеева, С.А. Бурцев // Юридическая наука. 2017. № 1. С. 97.

2. Аулов В.К. Дисциплинарная ответственность судей: генезис, понятие и процедура: автореферат дис. ... канд. юрид. наук: 12.00.11 / Владимир Константинович Аулов. - М., 2012. - С. 8.

3. Более 1,6 тыс. судей в России привлекли к дисциплинарной ответственности за пять лет [Электронный ресурс] // ТАСС. Режим доступа: https://tass.ru/ekonomika/6925496 (дата обращения 29.10.2021)

4. Володина Д. В. Юридическая ответственность судей при отправлении правосудия в Российской Федерации: современное состояние и направления развития: автореферат дис. ... канд. юрид. наук: 12.00.11 / Дарья Владимировна Володина. - Псков, 2012. - С. 11-12.

5. Дунюшкин П.А. Дисциплинарная ответственность судей в России: историко-правовой дискурс / П.А. Дунюшкин // Юридическая наука и практика: Вестник Нижегородской академии МВД России. 2013. № 23. С. 7.

6. Дунюшкин П.А. Становление и развитие института дисциплинарной ответственности судей: историкоправовое исследование: автореферат дис. ... канд. юрид. наук: 12.00 .01 / Павел Анатольевич Дунюшкин. Н. Новгород, 2013. - С. 12

7. айнов В.И. Генезис законодательства Российской Федерации о дисциплинарной ответственности судей / В.И. Кайнов, К. К.Нактанов // Право и государство: теория и практика. 2020. № 10 (190). С. 200

8. Конституция Российской Федерации (принята всенародным голосованием 12.12.1993 с изменениями, одобренными в ходе общероссийского голосования 01.07.2020) // Российская газета. 04.07.2020. № 144.

9. Об органах судейского сообщества в Российской Федерации: Федеральный закон от 14.03.2002 года № 30 Ф3 (ред. от 08.12.2020) [Электронный ресурс] Доступ из справ.-правовой системы «Консультант Плюс»

10. О внесении изменений и дополнений в Закон Российской Федерации «О статусе судей в Российской Федерации»: Федеральный закон от 15.12.2001 г. № 169-ФЗ [Электронный ресурс] Доступ из справ.-правовой системы «Консультант Плюс»

11. О внесении изменений в Закон Российской Федерации «О статусе судей в Российской Федерации»: Федеральный закон от 02.07.2013 № 179-Ф3 [Электронный ресурс] Доступ из справ.-правовой системы «Консультант Плюс» 
12. О внесении изменений в Закон Российской Федерации «О статусе судей в Российской Федерации» и Федеральный закон «Об органах судейского сообщества в Российской Федерации: Федеральный закон от 29.07.2018 № 243-Ф3 [Электронный ресурс] Доступ из справ.-правовой системы «Консультант Плюс»

13. О статусе судей в Российской Федерации: Закон Российской Федерации от 26.06.1992 № 31-32-1 (ред. от 05.04.2021) [Электронный ресурс] Доступ из справ.-правовой системы «Консультант Плюс».

14. О судебной системе Российской Федерации: Федеральный конституционный закон от 31.12.1996 № 1 -ФК3 (ред. от 08.12.2020) [Электронный ресурс] Доступ из справ.-правовой системы «Консультант Плюс»

15. Поздняков М.Л. Критерии оценки качества работы судей и дисциплинарная ответственность / М.Л. Поздняков. - СПб.: Институт проблем правоприменения при Европейском университете в Санкт-Петербурге, 2014. - C. 7. 